\title{
Identifying Popular Indigenous Leafy Vegetables for Sustainable Interest in Vegetable Production in the Tamale Metropolis in the Northern Region of Ghana
}

\author{
Fuseini Jacob Yakubu ${ }^{1}$, Patrick Kumah² \\ Department of Science, Bagabaga College of Education, P.O. Box ER 35, Tamale, Ghana \\ $(\mathrm{PhD})$, Department of Horticulture, Kwame Nkrumah University of Science and Technology, Kumasi- Ghana
}

\begin{abstract}
One way of achieving a sustained interest in vegetable production in a catchment area is to identify the most popular vegetable with high demand. The present study determined the Popular Indigenous leafy vegetables in the Tamale Metropolis in the Northern region of Ghana. A structured questionnaire was used to access the requisite data. The items were divided into sections. Most of the items were close-ended questions with few open-ended ones to make room for more different opinions. The questionnaire covered the bio data of leafy vegetable marketers and consumers, buying and selling volumes of leafy vegetables, Leafy vegetable marketers and prospective leafy vegetable consumers were the target population. The population of 60 marketers of leafy vegetables and 274 consumers in the Tamale Metropolis were considered. Respondents (consumers) were chosen as they came to buy leafy vegetables at the market. The data obtained was subjected to one way analysis of variance (ANOVA), using Statistical Package for Social Sciences (SPSS Version 16.0). Amaranthus dubius, Corchorus olitorius, and Hibiscus sabdariffa were rated the most popular leafy vegetables.
\end{abstract}

Keywords - Vegetable Production, Northern Region of Ghana.

\section{INTRODUCTION}

Ghana has varying climatic conditions across the country which coupled with inadequate food distribution channels has led to existence of different food crops in the different regions. Leafy vegetables serve as the main source of nutrients, especially in poor-resource households in the country. This is the case of the residents of northern Ghana, which comprises the Northern, Upper East and Upper West regions. Residents of Northern Ghana, consume significant quantities of greens gathered from their surroundings/farms (Amaglo and Nyarko, 2012).

Vegetables are the succulent edible plant parts that may be eaten as supplementary food or side dishes in raw state or in the cooked form and various preparations. They may be sweet, aromatic, bitter, hot and tasteless and sometimes require salting and considerable seasoning to render them more tasty and acceptable. Products of vegetables play an importantrole in the diet of West Africans. Some crops grown for one purpose may also be put to dual use, thus cowpea and cassava grown for their protein-rich seeds and carbohydrate-rich roots respectively, also have their leaves harvested for vegetables (Seidu et al., 2012). Traditional leafy vegetables play a very important role in income generation and subsistence. They provide employment for peri-urban dwellers because of their generally short, labour intensive production systems, low levels of investment and high yield (Schippers, 2000).

Several attempts have been made by successive governments and other development partners to improve the productivity of vegetable farmers in an effort to reduce poverty in the region through small scale irrigation schemes, dug-outs and others. These interventions have contributed to the improvement in the production and supply of vegetables in the area. (Fuseini, 2018).

Vegetables are also a preferred cash crop because of their potential for lifting poor farmers out of poverty. It is reported that urban agriculture can meet large parts of the urban demand for certain kinds of food such as fresh vegetables, poultry, potatoes, milk, fish and eggs. The most commonly grown urban vegetables are the most perishable (leafy) ones such as Amaranthus dubius, Corchorus olitorius, and Hibiscus sabdariffa, which have to be 
produced in market proximity. Sub-Saharan Africa regions are reported to have the world's lower intake of micronutrient-rich fruits and vegetables with the mean consumption being less than half the World Health Organization (2003) recommendations on daily intake of $400 \mathrm{~g}$ per capita per day in most countries. Low consumption of fruits and vegetables is the main contribution to micronutrients deficiencies, especially in populations with a low intake of nutrient-dense animal sources and dietary products (Seidu et al., 2012). It is an indisputable fact that leafy vegetables are vital sources of minerals and vitamins for human health and development. Climatic conditions such as high temperatures, low humidity short periods of rainfall in the northern part of the country does not favour the cultivation of crops withlong maturation periods. The main objective of the study was to determine the commonly grown leafy vegetables in the Tamale Metropolis in the Northern region of Ghana.

\section{A. Importance and benefits of Vegetables}

Vegetables are very vital to human, both economically and nutritionally. Economically, they are relatively cheap to grow and act as a quick source of income to many rural women (Ijeomah et al., 2012). Nutritionally, they are a good sources of vitamins, minerals and dietary fibre and water to aid digestion. Vegetables are rich in minerals such as potassium, sodium, calcium, iron, zinc and phosphorus. They also have high contents of thiamine, ascorbic acid, riboflavin and $\beta$-carotene. The water content is about $70 \%$ or more. They also contain many phyto-chemicals which are needed for health-promotion and disease prevention. Vegetables are consumed in very small quantities, and are used in almost every meal or used alone as salad or as a side dish with main meal (Ijeomah et al., 2012).

Many authors have documented the importance of indigenous leafy vegetables of Africa as valuable sources of food, income and traditional medicine. Traditional African vegetables are extremely important for nutrition and farm income throughout Africa. They often supply most of the daily requirements of proteins, minerals and vitamins of poor rural people (Adebooye, 2005).

Quite a large number of African indigenous leafy vegetables have long been known and reported to have health protecting properties and uses. Several of these indigenous leafy vegetables continue to be used for prophylactic and therapeutic purposes by rural communities. This indigenous knowledge of the health promoting and protecting attributes of African indigenous Leafy Vegetables (ALVs) is clearly linked to their nutritional and non-nutrient bioactive properties. ALVs have long been, and continue to be reported to significantly contribute to the dietary vitamin and mineral intakes of local populations (Smith, Francisca I. et al., (2007).

Indigenous vegetables are important sources of vitamins, minerals and other nutrients for rural families since ancient times. These substances protect us from illness and ensure proper metabolism. Since we cannot synthesize vitamins and minerals, they must also be supplied in the food we eat. Vitamins are often destroyed or lost during food processing. Othersources of vitamins and minerals are green leafy vegetables such as spinach and Kontomire (cocoyam leaves); both are found in southern Ghana. A larger variety of wild and cultivated leafy vegetables such as bitter leaf, cassava leaves, baobab leaves and Guinea sorrel are found in Northern Ghana (Kwapata, 1991).

Vegetables are a good source of roughages, which by providing an indigestible matrix stimulates intestinal muscles and keep them in working order and also prevent constipation through their laxative effect. The fibre content of vegetables generally adds to bulk of the food which prevents us from frequent hunger (Norman, 1992). Vegetables play an important role in the diet of West Africans. Some crops grown for one purpose may also be put to dual use, thus cowpea and cassava grown for their protein-rich seeds and carbohydrate-rich respectively also have their leaves harvested for vegetables (Okigbo, 1983). Vegetables are highly beneficial for maintaining health and preventing diseases. Dark green leafy vegetables provide high amounts of micro-minerals which play vital roles in nutrient metabolism and retard degenerative diseases (Darkwa and Darkwa, 2013). Vegetables are important dietary sources of nutrients, vitamins and fibre for humans' vital health and wellbeing. Well balanced diets rich in fruits and vegetables are especially valuable for their ability to prevent vitamin A and C deficiency (Sowley et al., 2011). Leafy vegetables contain many typical plant nutrients, but since they are photosynthetic tissues, their Vitamin K levels in relation to those of other fruits and vegetables, as well as other types of foods, are particularly notable. Leafy vegetables are typically low in calories, low in fat, high in protein per calorie, high in dietary fibre, high in iron and calcium, and very high in vitamin $\mathrm{C}$, carotenoids, lutein folate, magnesium as well as vitamin K (Schippers, 2000).

Some indigenous leafy vegetables such as okra, vegetable jute, impart a glutinous constituency to stew and soup and thus facilitate swallowing of food such as "Banku" "Fufu" and "Gari". It has been also discovered that vegetables are 
rich source of vitamins $\mathrm{K}, \mathrm{A}$, and $\mathrm{C}$ as well as minerals such as calcium, iron, phosphorus, some appreciable amount of thiamine, Niacin and riboflavin, carbohydrate and crude proteinas compared to exotic leafy vegetables (Schippers, 2000).

Green leafy vegetables are rich sources of carotene and vitamin $\mathrm{B}$ and $\mathrm{C}$. Carotene often called pre-vitamin $\mathrm{A}$ is changed to vitamin A indigestion. Food rich in vitamin $\mathrm{C}$ play an important supportive role in preventing Iron deficiency. Also, leafy vegetables are high in calcium, iron, and phosphorus. Furthermore, leafy vegetables are high in water content and fibre. Because of their succulence, they aid digestion (Schippers, 2000). Amaranthus dubius for instance is consumed as cooked leafy vegetable. Its leaves is known to be good food with medicinal properties for young children, lactating mothers and for patients with fever, haemorrhage, anaemia, constipation or kidney complaints (Schippers, 2002). It is rich in vitamin C and it is used to support the treatment of patients suffering from HIV/AIDS (Babalola et al., 2010).

Fibre is responsible for maintaining a healthy digestive tract and supporting a wide array of other bodily systems in less crucial ways as well. Eating green fruits and vegetables will help to ensure that you do not run into any problems with your digestive system. While each different green fruit and vegetable contains a slightly different mixture of vitamins, it is likely that any one that your choice will have a good source of at least one important nutrient of this type. Vitamin A and vitamin C are two of the most commonly occurring vitamins in these types of vegetables and fruits. Vitamin A helps your body to process a number of different nutrients, like calcium and potassium, while vitamin $\mathrm{C}$ is essential for the building up of your immune system and to prevent you from getting sick (WHO/FAO, 2003).

\section{MATERIALS AND METHODS}

Tamale Metropolis was the study area for this research work. Tamale Metropolis lies between latitudes $9^{\circ} 16^{\prime}$ and 9०34' North and longitudes $0^{\circ} 36^{\prime}$ and $0^{\circ} 57^{\prime}$ 'West. The Metropolis occupies approximately $750 \mathrm{~km}^{2}$ which is about $13 \%$ of the total land area of the Northern Region of Ghana (Sowley et al., 2011). Tamale has a tropical wet and dry/savannah climate with a pronounced dry season in the low-sun months, no cold season, and wet seasonis in the high-sun months. According to the Hold ridge life zones system of bioclimatic classification Tamale is situated in or near the tropical dry forest biome. The mean temperature is 27.9 degrees Celsius (82.3 degrees Fahrenheit). Average monthly temperatures vary by $5.5^{\circ} \mathrm{C}\left(9.9^{\circ} \mathrm{F}\right)$. The annual precipitation averages $1090 \mathrm{~mm}$ (42.9 inches) which is equivalent to 1090litres $/ \mathrm{m}^{2}$ (26.74gallons/ft ${ }^{2}$ ) or $90.8 \mathrm{~mm}$ (3.6 in) per month. On average there are 97 days per year with more than $0.1 \mathrm{~mm}$ (0.004 in) of rainfall. The driest weather is in December when an average of $3 \mathrm{~mm}(0.1 \mathrm{in})$ of rainfall occurs. The wettest weather is in September when an average of $231 \mathrm{~mm}$ (9.1 in) of rainfall occurs. On the average there are 2723 hours of sunshine per year. (Meteorological Service Department-Tamale, 2015). The study was conducted on some popular indigenous leafy vegetables in the Tamale Metropolis. A pilot survey was conducted to gather information on the popular indigenous leafy vegetables consumed in Tamale Metropolis. A structured questionnaire was used to access the requisite data. The items were divided into sections. Most of the items were close-ended questions with few open-ended ones to make room for more different opinions. The questionnaire covered the following broad areas; the bio data of leafy vegetable marketers and consumers, buying and selling volumes of leafy vegetables, and sources of the vegetables.

Leafy vegetable marketers and prospective leafy vegetable consumers were the target population. The population of 60 marketers of leafy vegetables and 274 consumers in the Tamale Metropolis were considered. Respondents (consumers) were chosen as they came to buy leafy vegetables at the market. The data obtained was subjected to one way analys is of variance (ANOVA), using Statistical Package for Social Sciences (SPSS Version 16.0).

\section{BIO DATA OF RESPONDENTS}

The age ranges of the marketers of leafy vegetables were 21-30, 31-40 and more than 41. Out of a total number of 60 vegetable marketers, $14(23.3 \%)$ of them were within the age range of $21-31$ years, $22(36.7 \%)$ of the total were within the age range of 31-40 years, majority (40\%) of the leafy vegetable marketers were in the age range of 41 years and above.

The level of education of leafy vegetable marketers were categorized into No formal education, Middle School Leaving Certificate (MSLC), Junior High School (JHS), Senior High School (SHS), and higher than SHS. Twenty five $(41.7 \%)$ of the marketers had no formal education while ten $(16.7 \%)$ were MSLC graduates. Junior High School (JHS) graduates were $15(29.7 \%)$ of the total number. Seven $(11.7 \%)$ of the total number of marketers 
were Senior High School SHS graduates and the remaining two $(3.3 \%)$ of marketers had education higher than SHS. Majority of the vegetable marketers had no formal education. Education higher than SHS category of marketers recorded the least.

Table.1: Bio-data of respondents

\begin{tabular}{|l|l|l|l|l|l|}
\hline \multicolumn{2}{|c|}{} & Marketers & Consumers \\
\cline { 3 - 6 } \multicolumn{2}{c|}{} & Frequency & $\%$ & Frequency & $\%$ \\
\hline \multirow{4}{*}{ Gender } & Male & & & 135 & 49.3 \\
\cline { 2 - 6 } & Female & & & 139 & 50.7 \\
\hline \multirow{5}{*}{ Age } & $21-30$ & 14 & 23.3 & 65 & 23.7 \\
\cline { 2 - 6 } & $31-40$ & 22 & 36.7 & 121 & 44.2 \\
\cline { 2 - 6 } & $41+$ & 24 & 40 & 88 & 32.1 \\
\hline & No formal & 25 & 41.7 & 127 & 46.4 \\
\cline { 2 - 6 } & MSLC & 10 & 16.7 & 05 & 1.8 \\
\cline { 2 - 6 } & JHS & 15 & 29.7 & 52 & 19.0 \\
\cline { 2 - 6 } & SHS & 07 & 11.6 & 63 & 23.0 \\
\cline { 2 - 5 } & Tertiary & 02 & 3.3 & 27 & 9.9 \\
\hline
\end{tabular}

Leafy vegetable marketers rated the vegetables as follows; 23 representing $38.3 \%$ of the total number of marketers rated Corchorus olitorius as the most popular leafy vegetable. Seventeen $(28.3 \%)$ of the marketers rated Hibiscus sabdariffa as the most popular leafy vegetable. Amaranthus dubius was rated next most popular leafy vegetable to Hibiscus sabdariffa with $13(21.7 \%)$ of the total number of marketers. Only $5.3 \%$ of the total number of marketers, rated cocoyam leaves, and 6.4\% rated bitter leaf as the most popular leafy vegetable in the Tamale Metropolis.

From Table 4.2, out of the total number of sixty marketers, 14 , $(23.3 \%)$ were in the age range of $21-30$ years; 22 marketers, representing $36.7 \%$ of the total number of the marketers were in the age range of 31-40 years. The remaining 24 marketers, representing $40 \%$, were in the age range of 41 years and above. With this statistics, the youngsters (21-30 year range), six marketers, representing $42.9 \%$ of this group, sold Corchorus olitorius most, none sold cocoyam leaves and four marketers, representing $28.6 \%$ of the population sold Hibiscus sabdariffa. Others were three marketers, representing $21.4 \%$, sold Amaranthus dubius and only one marketer,representing $7.1 \%$, sold bitter leaf. On the other hand, in the 31-40 year group who were interviewed, seven marketers, representing $31.8 \%$, sold
Out of 274 answers, $65(23.7 \%)$ were within the age range of 21-30 years, $121(44.2 \%)$ of the total number of consumers were within the age range of 31- 40 years, while the remaining $88(32.1 \%)$ were 41 years and above. 
Table.2: Popularity of leafy vegetable sold by age

\begin{tabular}{|c|c|c|c|c|c|}
\hline \multirow{2}{*}{$\begin{array}{l}\text { Indigenous leafy } \\
\text { vegetable }\end{array}$} & \multirow[t]{2}{*}{ Description } & \multicolumn{4}{|l|}{ Age } \\
\hline & & 21-30 & $31-40$ & $41+$ & Total \\
\hline \multirow[t]{3}{*}{ Corchorusolitorius } & Count & 6 & 7 & 10 & 23 \\
\hline & $\%$ within most popular leafy vegetable used at home & $26.1 \%$ & $30.4 \%$ & $43.5 \%$ & $100.0 \%$ \\
\hline & $\%$ within age of marketers & $42.9 \%$ & $31.8 \%$ & $41.7 \%$ & $38.3 \%$ \\
\hline \multirow[t]{3}{*}{ Cocoyam leaves } & Count & 0 & 3 & 3 & 6 \\
\hline & $\%$ within most popular leafy vegetable used at home & $0.0 \%$ & $50.0 \%$ & $50.0 \%$ & $100.0 \%$ \\
\hline & $\%$ within age of marketers & $0.0 \%$ & $13.6 \%$ & $12.5 \%$ & $10.0 \%$ \\
\hline \multirow[t]{3}{*}{$\begin{array}{l}\text { Hibiscus } \\
\text { sabdariffa }\end{array}$} & Count & 4 & 7 & 6 & 17 \\
\hline & $\%$ within most popular leafy vegetable used at home & $23.5 \%$ & $41.2 \%$ & $35.3 \%$ & $100.0 \%$ \\
\hline & $\%$ within age of marketers & $28.6 \%$ & $31.8 \%$ & $25.0 \%$ & $28.3 \%$ \\
\hline \multirow{3}{*}{$\begin{array}{l}\text { Amaranthus } \\
\text { dubius }\end{array}$} & Count & 3 & 5 & 5 & 13 \\
\hline & $\%$ within most popular leafy vegetable used at home & $23.1 \%$ & $38.5 \%$ & $38.5 \%$ & $100.0 \%$ \\
\hline & $\%$ within age of marketers & $21.4 \%$ & $22.7 \%$ & $20.8 \%$ & $21.7 \%$ \\
\hline \multirow[t]{3}{*}{ Bitter Leaf } & Count & 1 & 0 & 0 & 1 \\
\hline & $\%$ within most popular leafy vegetable used at home & $100.0 \%$ & $0.0 \%$ & $0.0 \%$ & $100.0 \%$ \\
\hline & $\%$ within age of marketers & $7.1 \%$ & $0.0 \%$ & $0.0 \%$ & $1.7 \%$ \\
\hline \multirow[t]{3}{*}{ Total } & Count & 14 & 22 & 24 & 60 \\
\hline & $\%$ within most popular leafy vegetable used at home & $23.3 \%$ & $36.7 \%$ & $40.0 \%$ & $100.0 \%$ \\
\hline & $\%$ within age of marketers & $100.0 \%$ & $100.0 \%$ & $100.0 \%$ & $100.0 \%$ \\
\hline
\end{tabular}

From Table 4.3 total number of 107 consumers representing $39.1 \%$ of the total number of 274 chose Corchorus olitorius as the most popular leafy vegetable used at home. Out of this, $50.5 \%$ of them were males and $49.5 \%$ were females. Thereby, indicated $40.0 \%$ of the total male consumers rated Corchorus olitorius as the most popular leafy vegetable used at home and $38.1 \%$ of the total female consumers rated Corchorus olitorius. Hibiscus sabdariffa was rated the second most popular leafy vegetable used at home as 90 consumers, representing $32.8 \%$ of the consumers. Out of this population, $50.0 \%$ of them were males and $50.0 \%$ were females, thereby, indicating $49.0 \%$ of the total male consumers rated Hibiscus sabdariffa as the most popular leafyvegetable used at home while $51.0 \%$ of the total female consumers rated Corchorus olitorius as most popular leafy vegetable used at home. Fifty one consumers, representing $18.6 \%$ of the total number of consumers, consisting of $18.5 \%$ males and $18.7 \%$ females indicated $49.0 \%$ of male consumers and $51.0 \%$ of female consumers respectively rated Amaranthus dubius as the most popular leafy vegetable used at home, placing it third on the list. Cocoyam leaves was rated the least with $1.5 \%$ and $8.0 \%$ by male and female consumers respectively of the total population of 4 consumers.

Table.3: Choice of popular leafy vegetable used by gender

\begin{tabular}{|c|c|c|c|c|}
\hline \multirow{2}{*}{$\begin{array}{l}\text { Indigenous leafy } \\
\text { vegetable }\end{array}$} & \multirow[t]{2}{*}{ Description } & \multicolumn{3}{|c|}{ Gender } \\
\hline & & Male & Female & Total \\
\hline \multirow[t]{3}{*}{ Corchorus olitorius } & Count & 54 & 53 & 107 \\
\hline & $\%$ within most popular leafy vegetable used at home & $50.5 \%$ & $49.5 \%$ & $100.0 \%$ \\
\hline & $\%$ within gender of consumers & $40.0 \%$ & $38.1 \%$ & $39.1 \%$ \\
\hline \multirow[t]{2}{*}{ Cocoyam leaves } & Count & 2 & 2 & 4 \\
\hline & $\%$ within most popular leafy vegetable used at home & $50.0 \%$ & $50.0 \%$ & $100.0 \%$ \\
\hline
\end{tabular}




\begin{tabular}{|l|l|l|l|l|}
\hline & \% within gender of consumers & $1.5 \%$ & $1.4 \%$ & $1.5 \%$ \\
\hline Hibiscus sabdariffa & Count & 45 & 45 & 90 \\
\hline & \% within most popular leafy vegetable used at home & $50.0 \%$ & $50.0 \%$ & $100.0 \%$ \\
\hline & \% within gender of consumers & $33.3 \%$ & $32.4 \%$ & $32.8 \%$ \\
\hline Amaranthus dubius & Count & 25 & 26 & 51 \\
\hline & $\%$ within most popular leafy vegetable used at home & $49.0 \%$ & $51.0 \%$ & $100.0 \%$ \\
\hline & \% within gender of consumers & $18.5 \%$ & $18.7 \%$ & $18.6 \%$ \\
\hline Bitter Leaf & Count & 9 & 13 & 22 \\
\hline & $\%$ within most popular leafy vegetable used at home & $40.9 \%$ & $59.1 \%$ & $100.0 \%$ \\
\hline & $\%$ within gender of consumers & $6.7 \%$ & $9.4 \%$ & $8.0 \%$ \\
\hline Total & Count & 135 & 139 & 274 \\
\hline & $\%$ within most popular leafy vegetable used at home & $49.3 \%$ & $50.7 \%$ & $100.0 \%$ \\
\hline & $\%$ within gender of consumers & $100.0 \%$ & $100.0 \%$ & $100.0 \%$ \\
\hline
\end{tabular}

Table 4.4 shows that, out of the total number of 274 consumers, 65 representing $23.7 \%$, were in the age range of 21-30 years, 121, consumers, representing $44.2 \%$ of the total number of the consumers were in the age range of 31 40 years, and 88 consumers, representing $32.1 \%$, were in the age range of 41 years and above. With this, 21 consumers, representing $32.3 \%$ of 21-30 year group, rated Corchorus olitorius was mostly used at home, none rated cocoyam leaves and 22 consumers, representing $33.8 \%$, rated Hibiscus sabdariffa. Seventeen consumers, representing $26.2 \%$ of this group (21-30 years), rated Amaranthus dubius was mostly used leafy vegetable at home and only five people, representing $7.7 \%$, rated bitter leaf. On the other hand, 31-40 year group who were interviewed, 55 consumers, representing 45.5\%, rated
Corchorus olitorius; two consumers, representing $1.7 \%$, rated cocoyam leaves as mostly used leafy vegetable at home, whilst 39 consumers (32.2\%), rated Hibiscus sabdariffa. Amaranthus dubius was rated by 16 consumers, representing $13.2 \%$ of the total number of this year group (31-40) of consumers, while nine consumers, representing $7.4 \%$ of them rated bitter leaf. Finally, 31 consumers, representing $35.2 \%$ of the total number of the 41 years and above group of consumers, rated Corchorus olitorius. Only two consumers, representing $2.3 \%$, rated cocoyam leaves and 29 (33\%) consumers rated Amaranthus dubius. Finally, eight consumers, representing $9.1 \%$, rated bitter leaf as mostly leafy vegetable used at home. It is clear that Corchorus olitorius was rated the highest with $39.1 \%$ with the concentration of $31-40$ year range of $45.5 \%$.

Table.4: Consumer rating ofleafy vegetables used by age

\begin{tabular}{|c|c|c|c|c|c|}
\hline \multirow{2}{*}{$\begin{array}{l}\text { Indigenous } \\
\text { leafy vegetable }\end{array}$} & \multirow[t]{2}{*}{ Description } & \multicolumn{4}{|l|}{ Age } \\
\hline & & $21-30$ & $31-40$ & $41+$ & Total \\
\hline Corchorus & Count & 21 & 55 & 31 & 107 \\
\hline \multirow{2}{*}{ olitorius } & \% within most popular leafy vegetable used at home & $19.6 \%$ & $51.4 \%$ & $29.0 \%$ & $100.0 \%$ \\
\hline & $\begin{array}{l}\% \text { within age } \\
\text { of consumers }\end{array}$ & $32.3 \%$ & $45.5 \%$ & $35.2 \%$ & $39.1 \%$ \\
\hline \multirow{3}{*}{$\begin{array}{l}\text { Cocoyam } \\
\text { leaves }\end{array}$} & Count & 0 & 2 & 2 & 4 \\
\hline & $\%$ within most popular leafy vegetable used at home & $0.0 \%$ & $50.0 \%$ & $50.0 \%$ & $100.0 \%$ \\
\hline & $\%$ within age of consumers & $0.0 \%$ & $1.7 \%$ & $2.3 \%$ & $1.5 \%$ \\
\hline Hibiscus & Count & 22 & 39 & 29 & 90 \\
\hline \multirow[t]{2}{*}{ sabdariffa } & $\%$ within most popular leafy vegetable used at home & $24.4 \%$ & $43.3 \%$ & $32.2 \%$ & $100.0 \%$ \\
\hline & $\%$ within age of consumers & $33.8 \%$ & $32.2 \%$ & $33.0 \%$ & $32.8 \%$ \\
\hline Amaranthus & Count & 17 & 16 & 18 & 51 \\
\hline dubius & $\%$ within most popular leafy vegetable used at home & $33.3 \%$ & $31.4 \%$ & $35.3 \%$ & $100.0 \%$ \\
\hline
\end{tabular}




\begin{tabular}{|l|l|l|l|l|l|}
\hline & \% within age of consumers & $26.2 \%$ & $13.2 \%$ & $20.5 \%$ & $18.6 \%$ \\
\hline Bitter Leaf & Count & 5 & 9 & 8 & 22 \\
\hline & \% within most popular leafy vegetable used at home & $22.7 \%$ & $40.9 \%$ & $36.4 \%$ & $100.0 \%$ \\
\hline & $\%$ within age of consumers & $7.7 \%$ & $7.4 \%$ & $9.1 \%$ & $8.0 \%$ \\
\hline Total & Count & 65 & 121 & 88 & 274 \\
\hline & $\%$ within most popular leafy vegetable used at home & $23.7 \%$ & $44.2 \%$ & $32.1 \%$ & $100.0 \%$ \\
\hline & \% within age of consumers & $100.0 \%$ & $100.0 \%$ & $100.0 \%$ & $100.0 \%$ \\
\hline
\end{tabular}

\section{CONCLUSION}

The survey conducted to identify the most popularly used indigenous leafy vegetables in the Tamale Metropolis, leafy vegetables were ranked in order of popularity by both leafy vegetable marketers and consumers. Amaranthus dubius, Corchorus olitorius, and Hibiscus sabdariffa were rated the most popular leafy vegetables, meanwhile Corchorus olitorius was rated the most popularly used indigenous leafy vegetable. Farmers of leafy vegetables should be encouraged to cultivate Amaranthus dubius, Corchorus olitorius and Hibiscus sabdariffa. This could help in the efforts to reduce unemployment situation in northern region of Ghana.

\section{ACKNOWLEDGEMENTS}

We wish to thank the Director of Savannah Agriculture Research Institute for granting us permission to conduct the experiment in their laboratory.

\section{REFERENCES}

[1] Adebooye, O. C., Ajayi, S. A. Baidu-Forson and Opabode, J. T. (2005). Seeds Constraint to Cultivation and Productivity of African Indigenous Leaf Vegetable. Institute for Natural Resources in Africa, Accra, Ghana.

[2] Babalola, O.O., Tugbobo O. S. and Daramola, A.S. (2010). Effect of Processing on the Vitamin C Content of Seven Nigerian Green Leafy Vegetables. Advance Journal of Food Science and Technology, 2(6): 303305.

[3] Darkwa, S. and Darkwa A. A. (2013). The Use of Indigenous Green Leafy Vegetables in the Preparation of Ghanaian Dishes. J Food Process Technol 4:286. DOI: $10.4172 / 2157-7110.1000286$.

[4] Fuseini Jacob Yakubu (2018). Motives of cultivating traditional leafy vegetables in Tamale Metropolis. International Journal of Environment, Agriculture and Biotechnology. Vol.-3, Issue-1

[5] Ijeomah, A. U., Ugwuona, F. U. and Ibrahim, Y. (2012). Nutrient Composition of three Commonly
Consumed Indigenous Vegetables of North Central Nigeria. Nigerian Journal of Agriculture, Food and Environment. 8(1):17 - 21.

[6] Meteorological service department (2019). Tamale climate \& temperature. Available Online: http://www.tamale.climatemps.com/ $20 / 04 / 2019$

[7] Norman, J.C. (1992). Tropical Vegetable Crops. Arthur H. Stock well Ltd. Great Britain. Pp. 10, 11b, $17 \mathrm{c}, 199 \mathrm{~d}$.

[8] Seidu, J. M., Bobobee, E.Y. H., Kwenin, W. K. J., Frimpong, R., Kubge, S. D., Tevor, W.J. and Mahama, A. A. (2012).Preservation of Indigenous Vegetables by Solar Drying.Vol. 7(6). Asian Research Publishing Network, ISSN 1990-6145 Pp 407- 415.

[9] Smith, Francisca I. and Pablo Eyzaguirre (2007). African Leafy Vegetables: Their Role In The World Health Organization's Global Fruit and Vegetables Initiative African Journal of Food Agriculture Nutrition and Development, Vol. 7, No. 3, 2007.Pp 117. Available online: http://www.ajfand.net/Volume7/No3/Smith-IPGRI11.pdf. 19/04/2019.

[10] Schippers, R.R. (2000). African Indigenous Vegetable. An Overview of the Cultivated Species. Chatham U.K. Natural resources Institute/ACP-EU Technical Centre for Agricultural and Rural Cooperation. 1-14.

[11] Schippers, R. R. (2002). African Indigenous Vegetables. An Overview of the Cultivated Species. Natural Resources Institute/ACP-EU Technical Centre for Agricultural and Rural Cooperation, Chatham, UK. Available on www.ajol.info/index.php/bajopas/article/download/99 279/88571Accessed 20/04/20019

[12] World Health Organisation/Food and Agriculture Organisation (2003). Promoting Fruit and Vegetable Consumption around the World. Retrieved from http://www.who.int/dietphysicalactivity/fruit/en/14/04/ $\underline{2019}$. 